\title{
Study on Professional Development Path of ESP Teachers in the Transformation of College English Teaching
}

\author{
Zhanyi He \\ College of Management, Changchun University of Chinese Medicine, Changchun, China \\ 229063980@qq.com
}

Keywords: college English teaching; ESP; professional development path

\begin{abstract}
On the basis of analysis of literatures, this paper points out that the focus and mainstream of college English teaching is now in the transformation from traditional English for General Purpose to English for Specific Purpose, analyzes the new requirements of professional development of ESP teachers under the new background, and further explores the professional development path of ESP teachers.
\end{abstract}

\section{Introduction}

College English teaching reform is a dynamic and developing process. College English teaching shows different characteristics in different historical stages with different requirements in teaching concept, teaching objective, teaching content and teaching modes. At present, college English teaching in China is now in the transformation from EGP (English for General Purpose) to ESP (English for Specific Purpose), and ESP will gradually become the focus and mainstream of college English teaching. How to adapt new trend and embrace new challenge, solve the bottleneck restricting the reform, and realize the success transformation and professional healthy development of ESP teachers is one of important issues for the academic field of college foreign languages to study and solve. Based on the new characteristics shown in the transformation of college English teachers, this paper explores the requirements of professional development of ESP teachers and puts forward professional development path of ESP teachers so as to provide references for the professional development of ESP teachers in our country.

\section{New characteristics shown in the transformation from EGP to ESP in college English teaching}

In April 2003, the Ministry of Education officially launched the "Teaching Quality and Teaching Reform Project in Colleges and Universities" (hereinafter referred to as "Quality Project"), which reflects that the new round of reform of college English teaching as the focus of "Quality Project" has entered the formal implementation stage. For over a decade, with the attention and support of leaders at all levels and the society, and with the great efforts of counterparts in foreign languages, major progress has been made in the reform, the comprehensive application capability of English for college students has been improved, positive contribution has been made in leading and promoting teaching reform of higher education in China and improving comprehensively the quality of talent cultivation, which has strategic significance at the same time.

However, the reform of college English teaching is undoubtedly a dynamic and developing process. With the deepening reform, college English teaching enters a new stage with new opportunities and challenges. And one of problems is it is urgent to conduct in-depth research and thinking on the orientation and development direction of foreign language teaching in colleges and universities.

Many scholars conduct explorations on the orientation of foreign language teaching. Ding Renlun et al (2013:17) based on summary and analysis of a large number of related literatures (such as Zhang Zhengdong, 2007; Dai Weidong, 2009; Hu Wenzhong, 2009, 2011; Cai Jigang, 2010, 
2011; Wang Shouren, Wang Haixiao, 2011; Yu Liming, Han Jianxia, 2012; Gui Shichun, 2012), believe that there are two problems in the teaching of college foreign language, lack of teaching planning and the inappropriate teaching orientation. About the orientation of college English, researchers point out that there are four focuses (one of is the relationship between EGP and ESP, the author noted), and put forward solutions for the orientation, that is, to be more specific, "The teaching of college foreign language in each college and university shall reorient in the national overall education planning and the blueprint of national foreign language education system, regional and academic advantages should be fully explored, current and future talent needs should be taken into consideration, and teacher education should be enhanced to improve foreign language teaching quality".

About the development direction of college English teaching, Cai Jigang (2007:31) points out that ESP is the only way and will be mainstream of the teaching of college English in all colleges and universities in the whole country, which has gradually become representative mainstream point of view to solve the orientation of college English teaching and problems of time-consuming, low-effective and separated foreign language teaching. At present, fundamental reforms have been conducted in learning forms of foreign language learners in Chines basic education, foreign language proficiency of high school graduates has improved markedly, and foreign language courses have been set in colleges and universities for more than sixty years, therefore, if college English teaching still follows traditional teaching with repetitive contents and single teaching objective, the diversified and individual learning requirements of college students cannot be satisfied. Therefore, the development of college English teaching faces the problem of directional choice. The focus of college English teaching should shift from the current EGP to ESP, especially academic English, so that foreign language learning and professional knowledge learning can be combined to transform from "foreign language learning" to "foreign language learning professional knowledge application", and establish the teaching objective of college English for professional knowledge learning and future work (Cai Jigang 2011).

\section{New requirements of professional development of ESP teachers in the transformation}

"The education policy based on teachers; good education based on good teachers". Teacher is the practitioner and domain power of education and teaching reform. The successful reform in college foreign language teaching depends to a large extent on whether teachers of college foreign language can keep pace with the times for sustainable development, adapt to the new situation, embrace new challenges with a forward-looking attitude, play the main role, and successfully achieve professional transformation and development.

Wang Yuping (2013:69-75) summarized many relevant literatures on Pedagogical Content Knowledge (PCK) of Shulman (1986) and Pedagogical Content Knowing (PCKg) of Cochran, built comprehensive model of knowledge development of pedagogical teaching of foreign language teachers, believed that the PCK structure of foreign language teachers include four basic aspects, subject matter knowledge, knowledge about students, situated teaching knowledge, and foreign language teaching strategies, and the improvement and professional development of subject teaching competence is the comprehensive understanding, effective integration and self-construction of the four knowledge.

PCK and PCKg are research theories for the education and development of foreign language teachers, which emphasize that teachers integrate various knowledge in education and teaching practice, organize knowledge from the perspective of teaching, and adapt to different learners' abilities and interests, with the characteristics of individuality, situationality and constructivism, and have strong theoretical value and practical significance for improving teachers' teaching ability and level and improving classroom teaching quality.

However, the subject knowledge discussed in PCK and PCKg is limited to foreign language subject knowledge, including basic language knowledge, language application skills and applied linguistics, literature, cross-cultural communication, and many other related professional knowledge and capabilities, which is suitable for foreign language professional teaching and foreign language 
general education carried out in traditional college English courses, whose teaching objective orientation is still traditional, that "students are able to use English language proficiently, understand English related cultural knowledge, and can perform cross-cultural communication in English”.

ESP is the English teaching with a specific subject area (such as finance, law, engineering, medicine, etc.) as main content, and its teaching objective orientation is to learn specific language knowledge (eg. vocabulary, syntax, text, genre) related to the subject, train and master the practical skills of communication in workplaces in foreign languages. Therefore, the essence of ESP is the intersection of disciplines. Objectively, ESP teachers are required to not only possess basic knowledge of the four aspects in PCK theory, but also be familiar with and master professional basic knowledge of a specific subject area so as to make themselves truly meaningful "compound talents”.

\section{Discussion on path of professional development of ESP teachers}

At present, the teaching staff engaged in ESP teaching in colleges and universities in China is mainly composed of college teachers who graduate from English majors, and professional teachers who have had overseas study experience and high English proficiency. They have advantages in ESP teaching, but there are deficiencies at the same time. Therefore, in order to adapt to the current transformation of college English teaching, it is an urgent to strengthen the construction of ESP teaching staff and accomplish the pre-employment and post-employment training for ESP teachers.

For teachers who graduate from English major, they should be encouraged to attend and study the related professional courses of their professional counterparts, study the second degree or postgraduate degree of related majors, and be familiar with and master the basic knowledge of related majors. The ESP teaching team is organized to regularly participate in ESP academic research and academic exchange activities at home and abroad, and ESP experts are invited to give lectures and training. Teachers are often organized to carry out such activities as ESP literatures reading, teaching case discussion, and collective lesson preparation. Teaching observation activities are conducted among ESP teachers to learn from each other and exchange work experience. Policy support and financial guarantees are provided for ESP teachers to participate in professional English textbook compilation, and apply for teaching research subject to improve the theoretical proficiency and teaching research ability.

For professional teachers volunteering to carry out ESP teaching and transfer to be foreign language teachers, support and guarantees are mainly provided for them in organization and personnel system, barriers in policies and systems shall be eliminated, equal treatment or preferential policies is adopted for workload identification, academic degree recognition, and work performance, etc. and professional title assessment, promotion, and etc. closely related to teachers' personal interests to eliminate worries and create a pleasant work and study environment for them to relax and develop. At the same time, training in various foreign languages are carried out regularly for foreign language teachers to further improve their practical foreign language skills.

In addition, in the initial stage of ESP teaching, foreign language teachers and professional teachers can try cooperative teaching to jointly undertake a certain ESP curriculum teaching, so that they can communicate with each other and learn from each other, and make common progress and growth in the practices.

\section{Conclusion}

College English teaching is an integral component of higher education system in China, and the quality of college English teaching is directly related to the quality of talent cultivation of higher education in China and the construction process and objective of human resource powerful nation. National foreign language proficiency is the significant strategic resources to ensure national security with dominant strategic position. Today, in the transformation from EGP to ESP in college foreign language, ESP teacher professional development research and planning design shall be 
carried out to solve the bottleneck of teachers that restrict reform and development, and realize the healthy and sustainable development of foreign language teaching in colleges and universities.

\section{Acknowledgements}

Program: Management model innovation program of Heath and Family Planning in Jilin province: Investigation and study on college English teaching reform method in medical college. Program No. 2017 G023.

\section{References}

[1] Cai Jigang. Characteristics and Solutions of College English Teaching in Transition [J]. Foreign Language Teaching and Research, 2007 (1).

[2] Cai Jigang. On the Reorientation of College English Teaching in China [J]. Foreign Language Teaching and Research, 2010 (4): 306-308.

[3] Cai Jigang. A Study of the Objective of College English Teaching in Mainland China from the Perspective of the College English Curriculum of the Universities of Hong Kong [J]. Foreign Language Teaching and Research, 2011, (4): 609-617.

[4] Ding Renlun, Dai Weidong. On the Positioning of Foreign Language Teaching in Colleges and Universities [J]. Foreign Language World, 2013, (2): 17-22.

[5] Dai Weidong. Based on National Conditions, Scientifically Plan to Improve Sustainable Development of Foreign Language Education in China [J]. Foreign Language World, 2009, (5): 2-9.

[6] Gui Shichun. Communication-oriented Foreign Language Teaching [J]. Modern Foreign Languages, 2012, (2): 193-196.

[7] Hu Wenzhong. The Strengths and Weakness of China's Foreign Language Education in the Past 60 Years [J]. Foreign Language Teaching and Research, 2009, (3): 163-169.

[8] Hu Wenzhong. Planning for Foreign Language Education is Imperative for China [J]. Foreign Language Teaching and Research, 2011, (1): 130-136.

[9] Wang Shouren, Wang Haixiao. On the State of College English Teaching in China and Its Future Development [J]. Foreign Languages in China, 2011, (5): 4-11, 17.

[10] Wang Yuping. On Development Pathways of Foreign Language Teachers PCK [J]. Foreign Language World, 2013, (2): 69-75.

[11] Yu Liming, Han Jianxia. Content- driven or Language-driven ---On College English Teaching in China [J]. Foreign Languages and Their Teaching, 2012, (3): 1-8.

[12] Zhang Zhengdong. On the Development of English Education in China [J]. Educational Research, 2007, (7): 78-83. 